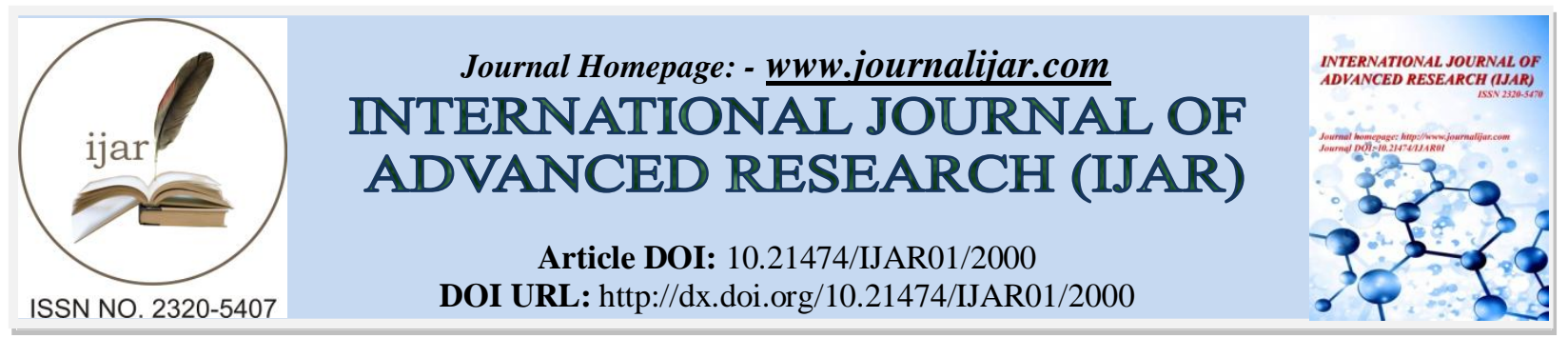

RESEARCH ARTICLE

\title{
CORRELATION BETWEEN VITAMIN D LEVEL AND RESPONSE TO THERAPY IN PATIENTS WITH CHRONIC HEPATITIS C VIRAL INFECTION.
}

\section{Al Shaimaa Zakaria El Sayed Mohamed ${ }^{1}$, Neveen Ahmed Abdul Hafeez Soliman ${ }^{2}$, Eman Ramadan AbdEl gwad $^{2}$ and Dalia Mohamed AbdEl-Hassib ${ }^{3}$.}

1. Resident phyisician at clinical pathology department, Benha Fever Hospital,Ministery of Health, Egypt.

2. Professor of Clinical and Chemical Pathology,Benha Faculty of Medicine, Egypt.

3. Lecturer of Clinical and Chemical Pathology,BenhaFaculty of Medicine,Egypt.

\section{Manuscript Info}

........................

Manuscript History

Received: 16 September 2016

Final Accepted: 25 October 2016

Published: October 2016

Key words:-

Vitamin D,Chronic Hepatitis C,25

Hydroxy vitamin $\mathrm{D}, 25(\mathrm{OH}) \mathrm{D}$.

\section{Abstract}

Objective:- This study aims to evaluate the relation between vitamin $\mathrm{D}$ level in chronic hepatitis $\mathrm{C}$ patients and the response to antiviral therapy.

Methods:- We examined 60 patients with chronic hepatitis C.Their vitamin D levels were compared with 25 healthy controls. The patients were treated with (pegylated interferon (PEG-IFN) plus ribavirin plus Sofosbuvir in weight-based doses(triple therapy) for 12 weeks. The 25(OH)D serum levels were measured using 25(OH) Vitamin D ELISA Kit.

Results:- There was a highly significant difference of vitamin D level between patients and controi group (17.9 $\pm 29.8 \mathrm{ng} \mathrm{ml}$ for patients versus $43.2 \pm 11.9 \mathrm{ng} \mathrm{ml}$ for control group),and all patients showed complete cure at end of treatment (no viremia detected at 12 weeks of treatment) regardless of vitamin D level.

Conclusion:- This study revealed that chronic hepatitis $\mathrm{C}$ patients have low vitamin D level and respond well to antiviral treatment including the new DAA(Sofosbuvir) So vitamin D level is an independent factor not corresponding to the level of the virological response to antiviral therapy.

Copy Right, IJAR, 2016,. All rights reserved.

\section{Introduction:-}

Hepatitis $\mathrm{C}$ is an infectious disease affecting the liver, caused by the hepatitis $\mathrm{C}$ virus (HCV) which is a small, enveloped, single-stranded and positive-sense RNA virus(Rosen,2011). The hepatitis C epidemic in Egypt had began during 1960-1980, when mass campaigns were conducted to control schistosomiasis through parenteral antischistosomal therapy administered by health-care workers using improperly sterilized glass syringes (Srickland,2006). The primary route of transmission of HCV in the developing world areblood transfusions and unsafe medical procedures(Maheshwari and Thuluvath,2010). Hepatitis $C$ virus infection usually is slowly progressive Thus,acute hepatitis is rarely daignosed as it is not clinically apparent (Wassmuth,2012). A hallmark of $\mathrm{HCV}$ infection is the establishment of chronic infection which is the persistence of HCV RNA in the blood for at least 6 months after onset of acute infection (Chen and Morgan,2006).Treatment of chronic HCV is aimed at slowing disease progression,eradicating the virus, preventing complications of cirrhosis, reducing the risk of hepatocellular carcinoma and decompensated liver disease (Yee et al.,2006). 
Major changes had emerged during the last few years in the therapy of patients with chronic hepatitis C, Several direct acting antiviral agents (DAAs) including Sofosbuvir had been developed showing potent activity against HCV and improving the rates of Sustained Virological response (SVR) even in difficult-to-treat chronic hepatitis C patients (Cholongitas and Papatheodoridis,2014). Vitamin D is a fat soluble vitamin metabolized by the liver and is converted to 25 dihydroxy vitamin $\mathrm{D}$ which is then converted to the active form $1,25(\mathrm{OH}) 2$ vitamin $\mathrm{D}$. Those with impaired liver function can have poor conversion.vitamin $\mathrm{D}$ has been found to have an immunological role( modulate immunity principally via regulating T-cell function).Vitamin D Receptor (VDR) has been found to be expressed on virtually every type of cell involved in immunity (Bruce et al.,2010).

A number of studies suggest that vitamin D and its metabolites can synergize with IFN treatment to directly inhibit HCV RNA replication in vitro(Gal-Tanamy et al.,2011), and There is a positive correlation between 25(OH)D levels and the likelihood of achieving an SVR (Gutierrez et al.,2011).

\section{Subjects and Methods:- subjects:-}

This study was conducted on 85 subjects subdivided into two groups.

\section{Patient group:-}

* This group included 60 patients with chronic hepatitis $\mathrm{C}$ attending the Liver Center for treatment.

* They were 46 males and 14 females since June 2015 to August 2015.

* The patients were treated with (pegylated interferon (PEG-IFN) plusribavirin plus Sofosbuvir in weight-based doses(triple therapy) for 12 weeks.

- All patients made routinely quantitative PCR for HCV-RNA before(baseline time) and after treatment to follow the response to therapy.(we obtained their results from patients files in the Liver Center).

\section{Inclusion criteria:-}

a) HCV- RNA positive for 6 months.

b) fresh candidates for therapy.

\section{Exclusion criteria:-}

HBsAgpositive .

\section{Control group:-}

* This group included twenty five apparently healthy individuals of matched age and sex.

* The circulating 25-hydroxy vitamin D levels were measured using 25(OH) Vitamin D ELISA Kit.

\section{Methods:-}

\section{Sampling:-}

3 milliliters of venous blood were withdrawn under aseptic precautions for serum separation from patients and control groups,after clotting the sample was centrifuged and the resultant serum was used for $25(\mathrm{OH}) \mathrm{D}$ measurement.

\section{methods:-}

To measure 25(OH)D we used Purified Human 25(OH)D antibody to coat microtiter plate wells, made solid-phase antibody,then we added 25(OH)D to thewells, Combined 25(OH)D antibody which with HRP labeled, became antibody - antigen - enzyme-antibody complex,After washing completely,TMB substrate solution was added,TMB substrate became blue colour. At HRP enzyme-catalyzed, reaction was terminated by the addition of a sulphuric acid solution and the colour change was measured spectrophotometrically at a wavelength of $450 \mathrm{~nm}$. The concentration of $25(\mathrm{OH}) \mathrm{D}$ in the samples was then determined by comparing the O.D. of the samples to the standard curve. (Plate Reader (IVD)., serial number 1912).

\section{Statistical analysis:-}

Statistical Package for Social Sciences (SPSS) version 19 software( SPSS Inc., Chicago,USA) was used to analyze and tabulate collected data. Categorical data were presented as numbers and percentages. Quantitative data were expressed as mean and standard deviation. Chi square test (X2) was used to compare between 2 or more categorical 
groups. Student t-test, "Z" of Mann Whitney and U-test were used to compare means of two independent groups. Pearsons correlation analysis and Spearman Rho correlation were used to compare between quantitative variables. The accepted level of significance (predictive value) was $>0.05$.

\section{Results:-}

By comparing between patient and control groups, it was found that,there was statistically non significant difference as regards to both age groups( $>45$ and $<45$ years old).It also showed that $46.7 \%$ of patients are older than 45 years old ( $>$ > 0.05), and there was negative correlation between age of patients group and vitamin D levels (Fig:1).andthere was statistically no significant difference between patients and control groups as regard togender ( $p$ $>0.05)$.

There was a highly significant difference of Vitamin D level between patients and control groups,(patients were lower than controls) $(17.9 \pm 29.8 \mathrm{ng} / \mathrm{ml}$ for patients versus $43.2 \pm 11.9 \mathrm{ng} / \mathrm{mlfor}$ control)(p <0.001) (Tab:1).

there was statistically no significantdifference between male and female regarding to Vitamin D level in studied groups ( $\mathrm{p}>0.05$ ) (Tab:2).

There was a highly significant difference of PCR level between baseline time and 12 weeks(end) of treatment in patients group ( $p>0.001)$ (Tab:3), and all cases responded 100\% to treatment regardless vitamin D level (Tab:4).

Figure 1:- Correlation between age and Vitamin D baseline level $(\mathrm{ng} / \mathrm{ml})$ in patients group.

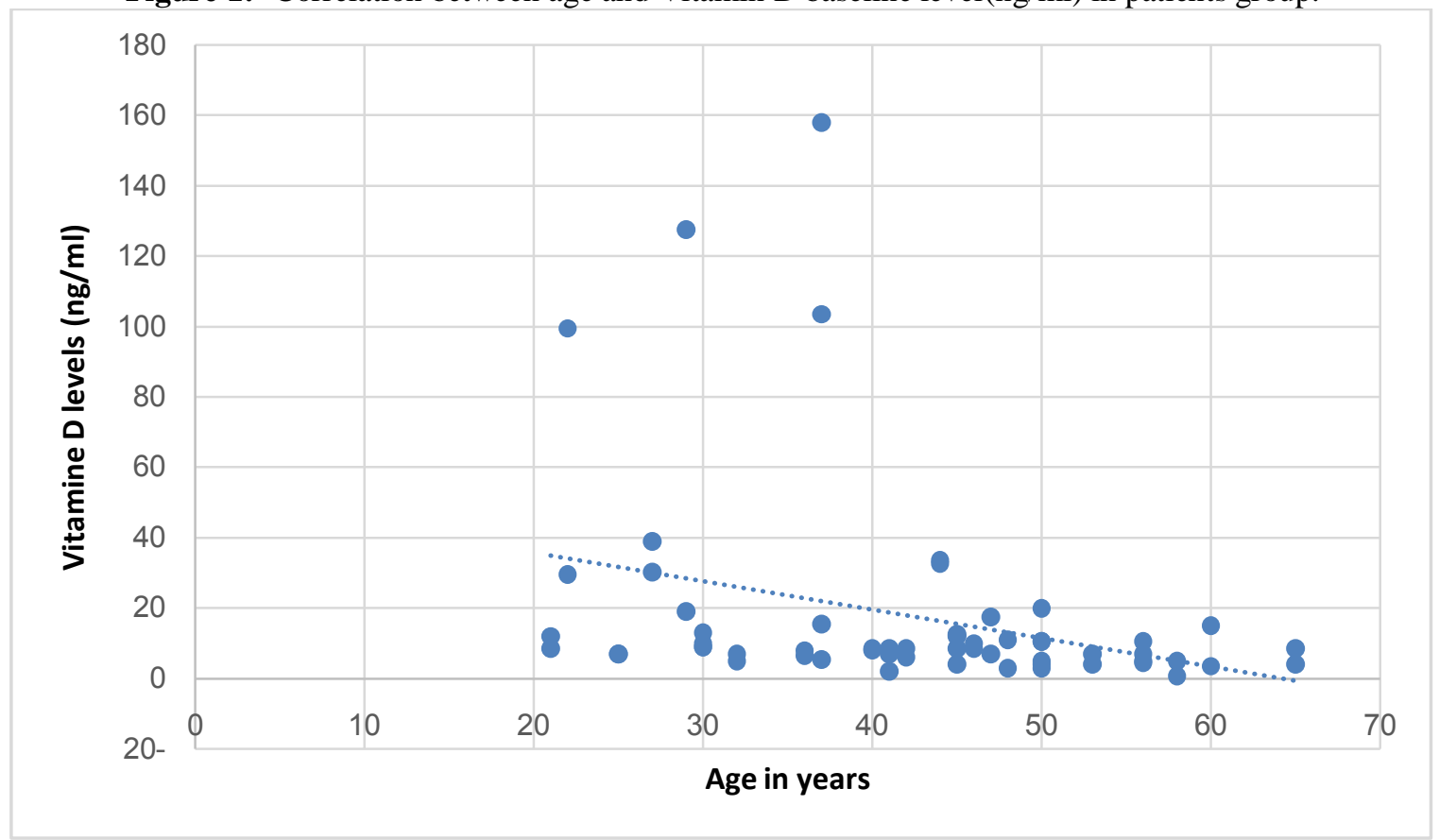


Table 1:- comparison between patients and control groups regarding Vitamin D baseline level(ng/ml).

\begin{tabular}{|c|c|c|c|c|c|c|c|c|}
\hline Vitamin D & $\mathbf{N}$ & Min & Max & Mean \pm SD & Median & IQR & Z & P value \\
\hline Patients & 60 & 0.7 & 158 & $17.9 \pm 29.8$ & 8.5 & 7.25 & -6 & $<0.001$ \\
\hline Control & 25 & 23 & 61 & $43.2 \pm 11.9$ & 44 & 21.25 & & \\
\hline
\end{tabular}

Table 2:- comparison between male and female regarding Vitamin D baseline level(ng/ml) in studied groups.

\begin{tabular}{|c|c|c|c|c|c|c|c|c|c|}
\hline Group & Gender & No & Min & Max & Mean \pm SD & Median & IQR & Z & P value \\
\hline Patients & Male & 46 & 0.7 & 99.5 & $11.8 \pm 15.2$ & 8.5 & 6.25 & -1.59 & 0.11 \\
\hline & Female & 14 & 4.5 & 158 & $38.1 \pm 51.6$ & 10.25 & 44.24 & & \\
\hline & Male & 20 & 23 & 61 & $45.2 \pm 11.3$ & 46.5 & 16.13 & & \\
\hline Control & Female & 5 & 23.5 & 54 & $35.1 \pm 11.9$ & 33 & 20.75 & -1.77 & 0.08 \\
\hline
\end{tabular}

Table 3:- Comparison of PCR level between Baseline time and12 weeks of treatment in patients group.

\begin{tabular}{|c|c|c|c|c|c|c|c|}
\hline PCR & Min & Max & Mean \pm SD & Median & IQR & Z & P value \\
\hline Baseline & 7168 & 11625018 & $2204352 \pm 3139290$ & 535341.5 & 3112914 & 9.44 & $>0.001$ \\
\hline $\begin{array}{c}\text { 12 weeks of } \\
\text { treatment }\end{array}$ & 0 & 0 & 0 & 0 & 0 & & \\
\hline
\end{tabular}

Table (4): Effect of Vitamin D level in PCR responds to 12 weeks of treatment:

\begin{tabular}{|c|c|c|c|c|}
\hline Respond & No & Min & Max & Mean \pm SD \\
\hline Responder & 60 & 0.7 & 158 & $17.9 \pm 29.8(\mathrm{ng} / \mathrm{ml})$ \\
\hline Non respondert & 0 & 0 & 0 & 0 \\
\hline
\end{tabular}

\section{Discussion:-}

This case-control was intended to evaluate the relationship of $25(\mathrm{OH}) \mathrm{D}$ level and the response to antiviral therapy in chronic hepatitis $\mathrm{C}$ viral infection.

In this study,the mean age of our patients was $42.1 \pm 11.6$ (46.7\% were older than 45 years old) and there was no significant difference between patients and control groups as regard to age in years and as regard to gender (most of patients $76.7 \%$ were males while females represented 23.3\%).This was in agreement withEl-Zanaty and Way (2009) who reported that prevelance of chronic HCV in Egypt is higher among men than women and increases with age (reaching $>25 \%$ among persons aged $>50$ years). This was also reported by El-Sadawyand coworkers (2004)whoreported that the high risk of exposure to HCV infection is among males (due to the relative increase in males outdoor activities). While this was disagreed by Zhili and colleagues (2016) who found that The frequency of HCV prevalence was significantly higher in female patients compared to males before ages 60 , while the opposite result was observed after 60 years.

In this study there was a highly significant difference of Vitamin D level between patients and control groups (lower levels in patients), these outcomes were in concurrence with ElHusseinyand associates (2012)who found a significant reduction of vitamin $\mathrm{D}$ and its active metabolites in HCV genotype 4-infected Egyptian patients compared to control groups, and with Targherand colleagues (2007)who reported that patients with chronic liver disease of any cause have lower levels of serum $25(\mathrm{OH})$ vitamin D,this was explained by Schiefke and coworkers(2005) and Nair (2010) to be due to impaired 25-hydroxylation of vitamin D and impaired synthesis of vitamin D binding protein and impaired absorption of vitamin D due to impaired bile acid production or gut edema associated with portal hypertention.

Our study showed no significant difference between male and female regarding to Vitamin D baseline level in groups, This disagreed with Masanori and coworkers (2015)who reported lower level of vitamin D in female patients.

The present study demonstrated that there was a highly significant difference of PCR level between Baseline time and 12 weeks(end) of treatment in patients group ( $p>0.001$ ) (all patients became negative for HCV-RNA),These outcomes were in concurrence withFoster and associates (2015)who reported that sofosbuvir has been a breakthrough new medication for the treatment of patients with chronic hepatitis $\mathrm{C}$ and has an excellent sustained virologic response rates in patients with unfavorable baseline characteristics. 
Our study showed that all cases respond $100 \%$ to treatment regardless vitamin D level,this was agreed by AbdElalim and colleagues (2015) who reported that vitamin D status has no correlation with viral load and there was no significant association between vitamin D deficiency and the antiviral therapy response, while was disagreed by Petta and coworkers (2010)who reported that low vitamin D was linked to severe fibrosis and low SVR on IFNbased therapy for CHC patients.

\section{Conclusion:-}

This study revealed that chronic hepatitis $\mathrm{C}$ patients have low vitamin $\mathrm{D}$ level and respond well to antiviral treatment including the new DAA(Sofosbuvir) So vitamin D level is an independent factor not corresponding to the level of the virological response to antiviral therapy.

\section{Acknowledgment:-}

We acknowledge the great support to all staff members and nursing team in the Liver Center in Benha Fever Hospital, Egypt for their help and cooperation in this work.

\section{References:-}

1. AbdElalim, M.H., Zaky, D.Z., Motawae, L.A., Mohamed, N.A. and Nagib, A.N. (2015):Interplay between vitamin D status and antiviral therapy among chronic hepatitis C Egyptian patients. Journal of the Egyptian Society of Parasitology., 45(1):17-22.

2. Bruce, D., Ooi, J.H., Yu, S.and Cantorna, M.T. (2010): Vitamin D and host resistance to infection: Putting the cart in front of the horse. Experimental biology and medicine., 235 (8): 921-927.

3. Chen, S.L. and Morgan, T.R. (2006): The Natural History of Hepatitis C Virus (HCV) Infection,Int. J. Med. Sci., 3(2):47-52 .

4. Cholongitas, E. and Papatheodoridis, G.V. (2014): Sofosbuvir: a novel oral agent for chronic hepatitis C,Ann.Gastroenterol., 27(4):331-337.

5. EL Husseiny, N.M., Fahmy, H.M.,Waleed, A.M. and Hisham, H.A. (2012): Relationship between vitamin D and IL-23 ,IL-17 macrophage chemoattractant protein-1 as markers of fibrosis in hepatitis c virus Egyptians. W. J.Hepatol., 4(8):242-247.

6. El Sadawy, M., Ragab, H., El Toukhy, H., El Mor, A., Mangoud, A., and Eissa, H. (2004): Seroprevalence and associated risk factors. J. Egypt. So.Parasitol., 34 (1):367-77.

7. El-Zanaty, F. and Way, A. (2009): Egypt demographic and health survey 2008, Egypt demographic and health surveys.Ministery of health. Cairo.

8. Foster, G.R., Pianko, S., Brown, A.,Forton, D., Nahass, R.G., George, J., Barnes, E., Brainard, D.M., Massetto, B., Lin, M., Han, B., McHutchison, J. G., Subramanian, G.M., Cooper, C., Agarwal, K.and BOSON Study Group(2015): Efficacy of sofosbuvir plus ribavirin with or without peginterferon-alfa in patients with hepatitis $\mathrm{C}$ virus genotype 3 infection and treatment-experienced patients with cirrhosis and hepatitis C virus genotype 2 infection. Gastroenterology., 149(6):1462-1470.

9. Gal-Tanamy,M.,Bachmetov, L.,Ravid, A.,Erman, A. and Tur-Kaspa, R. (2011): Vitamin D;an innate antiviral agent suppressing hepatits $C$ virus in human hepatocytes.Hepatology., 54(5):1570-1579.

10. Gutierrez, J.A.,Parikh, N. and Branch, A.D.(2011):Classical and emerging roles of vitamin D in hepatits C virus infection.Semin.Liver.Dis.,31(4):387-398.

11. Maheshwari, A. and Thuluvath, P.J. (2010):Management of acute hepatitis C .Clin.Liver.Dis., 14(1):169176.

12. Masanori Atsukawa, Akihito Tsubota, Noritomo Shimada, Kai Yoshizawa, Hiroshi Abe, Toru Asano, Yusuke Ohkubo, Masahiro Araki, Tadashi Ikegami, Chisa Kondo, Norio Itokawa, Ai Nakagawa, Taeang Arai, Yoko Matsushita, Katsuhisa Nakatsuka, Tomomi Furihata, YoshimichiChuganji, Yasushi Matsuzaki, Yoshio Aizawa, Katsuhiko Iwakiri (2015): Influencing factors on serum 25-hydroxyvitamin $\mathrm{D}_{3}$ levels in Japanese chronic hepatitis C patients.BMC.Infectious.Diseases., 15:344.

13. Nair, S. (2010):Vitamin D Deficiency and Liver Disease.Gastroenterol.Hepatol. (N Y).,6(8): 491-493.

14. Petta, S., Cammà, C., Scazzone, C.,Tripodo, C.,Di Marco, V.,Bono, A.,Cabibi, D.,Licata, G.,Porcasi, R.,Marchesini, G.and Craxí, A. (2010): Low vitamin D serum level is related to severe fibrosis and low responsiveness to interferon-based therapy in genotype 1 chronic hepatitis C. Hepatology., 51(4):1158-1167.

15. Rosen, H.R.(2011):"Clinical practice:Chronic hepatitis C infection",The New England.Journal.of Medicine., 364 (25): 2429-2438. 
16. Schiefke, I., Fach, A., Wiedmann, M., Aretin, A.V., Schenker, E., Borte, G., Wiese, M. and Moessner, J. (2005): (Reduced bone mineral density and altered bone turnover markers in patients with non-cirrhotic chronic Hepatitis B or C infection).world. j. Gastro- enteral.,11(12):1843-1847.

17. Srickland G (2006):Liver disease in Egypt;hepatitis $C$ superseded schistosomiasis as a result of iatrogenic and biological factors. Hepatology.,43(5):915-922.

18. Targher, G., Bertolini, L.,Scala, L.,Cigolini, M.,Zenari, L.,Falezza, G. and Arcaro, G. (2007): Associations between serum 25-hydroxyvitamin D3 concentrations and liver histology in patients with non-alcoholic fatty liver disease.Nutr.Metab.Cardiovasc Dis., 17(7):517-524.

19. Wassmuth, J., (2012): Epidemiology,transmission and natural history.Hepat. Mon.,12(3): 185-189.

20. Yee, H.S.,Currie, S.L., Darling, J.M. and Wright, T.L. (2006): Management andTreatment of Hepatitis C Viral Infection: Recommendations from the Department of Veterans Affairs Hepatitis C Resource Center Program and the National Hepatitis C Program Office. Am. J.Gastroenterol.,101(10):2360-2378.

21. ZhiLiNiu, PingAnZhang,and YongQing Tong (2016):Age and gender distribution of Hepatitis C virus prevalence and genotypes of individuals of physical examination in WuHan, Central China,Springerplus., 5(1): 1557. 